\title{
Performance of Rabbits Fed Diets Containing Different Levels of Energy and Lesser Galangal (Alpinia Officinarum)
}

\author{
Sh. A. M. Ibrahim (Corresponding author) \\ Animal Production Department, National Research Centre, Dokki, Giza, Egypt \\ Tel: 20-1-0169-4188 E-mail: shawki_nre@yahoo.com \\ H. A. A. Omer \\ Animal Production Department, National Research Centre, Dokki, Giza, Egypt \\ Tel: 20-1-1408-9312 E-mail: hamedomer2000@yahoo.com \\ Ali F. A. F. \\ Animal Production Department, National Research Centre, Dokki, Giza, Egypt \\ Tel: 20-1-0652-7044 E-mail: mf_ahmed@live.com \\ El-Mallah G. M. \\ Animal Production Department, National Research Centre, Dokki, Giza, Egypt \\ Tel: 20-1-0652-7044Ｅ-mail: gmelmallah@yahoo.com
}

Received: March 1, 2011 Accepted: March 15, $2011 \quad$ Published: December 1, 2011

doi:10.5539/jas.v3n4p241

URL: http://dx.doi.org/10.5539/jas.v3n4p241

\begin{abstract}
This work aimed to study the effect of two different levels of ration energy supplemented with Alpinia officinarum. Rabbits were classified into six equal groups (G1-G6). The $1^{\text {st }}$ and $4^{\text {th }}$ groups received basal ration with $100 \%$ and $90 \%$ energy requirement and served as first and second control respectively. The $2^{\text {nd }}$ and the $3^{\text {rd }}$ groups received basal ration with $100 \%$ energy requirement supplemented with Alpinia officinarum at the level of 0.5 and $1.0 \%$, respectively. The $5^{\text {th }}$ and $6^{\text {th }}$ groups received basal ration with $90 \%$ energy requirement with Alpinia officinarum at the level of 0.5 and $1.0 \%$, respectively.

The $90 \%$ energy containing diet showed significant increased $(\mathrm{P}<0.05)$ in $\mathrm{DM}$ and CF digestibility, while EE digestibility was significantly $(\mathrm{P}<0.05)$ decreased. Lesser galangal as feed additives showed significant $(\mathrm{P}<0.05)$ increased in DM, OM, CF, NFE digestibility and TDN value. There were significant interaction values between energy and supplementation levels on digestibility coefficient of DM, OM, CF, EE, NFE and TDN value. Supplementation of Lesser galangal at $0.5 \%$ or $1 \%$ significantly increased final body weight gain, ADG, feed conversion, while slightly decreased feed intake. The $90 \%$ energy and $1 \%$ lesser galangal $\left(\mathrm{G}_{6}\right)$ recorded the best values of final body weight, body daily weight gain and feed conversion.

The interaction values between energy and lesser galangal levels significantly increased $(\mathrm{P}<0.05)$ the carcass weight, dressing percentages and carcass cuts. The $90 \%$ energy and $1 \%$ lesser galangal $\left(\mathrm{G}_{6}\right)$ recorded the best values of carcass weight, dressing percentages and carcass cuts. Lesser galangal significantly $(\mathrm{P}<0.05)$ decreased the lungs (weight and $\%$ of SW); content of stomach and empty of small intestine (weight and $\%$ of $\mathrm{SW})$. The interaction values between energy and lesser galangal levels significantly $(\mathrm{P}<0.05)$ increased the liver and total internal offal's (\% of SW); lungs, full and content of stomach as well as digestive tract content (weight, $\mathrm{g}$ and $\%$ of SW).

Dietary $90 \%$ energy requirements with $0.5 \%$ or $1 \%$ lesser galangal showed the high values of net revenue, economical efficiency and relative economic efficiency, while recorded the low value of feed cost/ $\mathrm{kg}$ live body
\end{abstract}


weight (LE). Rabbits received the $90 \%$ energy requirement with $0.5 \%$ lesser galangal recorded the highest value of relative economic efficiency (111.4\%) and the lowest value of feed cost/ $\mathrm{kg}$ live body weight (5.45 LE).

Keywords: Alpinia officinarum, Galangal, Rabbits, Growth performance, Digestibility, Carcass characteristics, Economic evaluation

\section{Introduction}

Recently, it has found that some medicinal plants had some properties as growth enhancement. Some medicinal plants can be used as natural additives, tonic and restoratives in animal and poultry diets (Boulos, 1983), or to improve either of growth performance, immunity and the viability (El-Hindawy et al., 1996). Alpinia officinarum rhizome has long been used as an anti-inflammatory, an analgesic, a stomachic and a carminative in traditional medicine (Lee et al., 2009).

Lesser galangal (Kholengan) used is the dried rhizomes of Alpinia officinarum (AO) belonging to the family zingeberaeceae (Srividya et al., 2010). The major component of lesser galangal is 1, 8-cineole (50\%) with the balance largely made up of terpenes. The root contains a volatile oil resin, galangol, kaempferid, galangin and alpinin, starch, etc. The active principles are the volatile oil and acrid resin. (Srividya et al., 2010). Methanol extract of (AO) rhizome showed a majority of the compound including tannins, alkaloids, flavonoids and saponins (Subramanian et al., 2009).

The hypothesis that if any component lowered circulating glucose levels, indicating that this component is enhancing insulin sensitivity as well as improving the utilization of low energy diet. Some essential oils lowered circulating glucose levels and systolic blood pressure, suggesting that these natural products are enhancing insulin sensitivity (Talpur et al., 2005). Darylheptanoid isolated from lesser galangal suppressed the lipopolysaccharide (Yadav et al., 2003). Six diarylheptanoids isolated from the rhizome of (AO) inhibitors of nitric oxide production in the lipopolysaccharide-activated macrophage cell (Lee et al., 2006). Pancreatic lipase inhibitors from the rhizome of (AO) may be effective as hypolipidemic agents (Shin et al., 2004). Galangin could lead to the development of new combination antibiotics against methicillin-resistant Staphylococcus aureus infection (Lee, 2008). Diarylheptanoid could interact with subunit A of Escherichia coli DNA gyrase (Subramanian et al., 2009).

Alpinia officinarum has hemostatic actions that may provide a therapeutic potential for the management of deficient primary hemostasis (Subramanian et al., 2009). Alpinia officinarum rhizomes is viable therapeutic for the treatment of acute and chronic arthritis (Lee et al., 2009). All diarylheptanoids exhibited potential antiviral activity against influenza virus in vitro (Sawamura et al., 2010). Alpinia officinarum rhizome as anti-inflammatory drug may be explained by the inhibition of nitric oxide production in activated macrophages (Lee et al., 2006). Galangin may be agent for prevention of skin cancer ( $\mathrm{Lu}$ et al., 2007). Alpinia officinarum may be the potential source of free radical scavengers from natural plant (Kim et al., 1997). The three new diarylheptanoids isolated from the ethanol extract from the rhizomes of Alpinia officinarum are antibacterial active (Zhang et al., 2010).

This work aimed to evaluate the efficacy of the mixture of (AO) as feed additives in improving the utilization of low energy rabbit diet as well as growth performance.

\section{Materials and Methods}

A total number of 54 male New Zealand White rabbits aged 4 weeks with an average body weight of $409 \pm$ $4.92 \mathrm{~g}$, were divided into six equal groups. The basal experimental diet was formulated and pelleted to cover the nutrient requirements of rabbits as a basal diet according to (NRC, 1977) as shown in (Table 1). The feeding period was extended for 56 days, and the experimental groups were classified as follow:

Group 1 basal diet with $100 \%$ energy requirement and served as control (G1),

Group 2 basal diet with $100 \%$ energy requirement $+0.5 \%$ lesser galangal (G2),

Group 3 basal diet with $100 \%$ energy requirement $+1 \%$ lesser galangal (G3),

Group 4 basal diet with $90 \%$ energy requirement and served as control (G4),

Group 5 basal diet with $90 \%$ energy requirement $+0.5 \%$ lesser galangal (G5) and

Group 6 basal diet with $90 \%$ energy requirement $+1 \%$ lesser galangal (G6).

Rabbits individually housed in galvanized wire cages $(30 \times 35 \times 40 \mathrm{~cm})$. Stainless steel nipples for drinking and feeders allowing recording individual feed intake for each rabbit were supplied for each cage. Feed and water 
were offered ad libitum. Rabbits of all groups were kept under the same managerial conditions and were individually weighed, and feed consumption was individually recorded weekly during the experimental period.

At the end of the experimental period, all rabbits in feeding trials were used in digestibility trials over period of 7 days to determine the nutrient digestibility coefficients and nutritive values of the tested diets. Feces were daily collected quantitatively. Feed intake of experimental rations and weight of feces were daily recorded. Representative samples of feces was dried at $60^{\circ} \mathrm{C}$ for $48 \mathrm{hrs}$, ground and stored for later chemical analysis.

Six representative rabbits from each treatment were randomly chosen and fasted for 12 hours before slaughtering according to Blasco et al. (1993) to determine the carcass measurements. Edible offal's (Giblets) included heart, lungs, liver, testes, kidneys and spleen were removed and individually weighed. Digestive tract was separated into stomach, small and large intestine, where full and empty weights were recorded. Weights of carcass, giblets and external offal's were calculated as percentages of slaughter weight (SW). Hot carcass was weighed and divided into fore, middle and hind parts. The 9,10 and $11^{\text {th }}$ ribs were frozen in polyethylene bags for later chemical analysis. The best ribs of samples were dried at $60 \mathrm{C}^{\circ}$ for $24 \mathrm{hrs}$. The air-dried samples were analyzed for DM, EE and ash according to the A.O.A.C. (2000) methods, while CP percentage was determined by difference as recommended by O'Mary et al. (1979).

Chemical analysis of experimental rations and feces were analyzed according to A.O.A.C (2000) methods. Neutral detergent fiber (NDF), acid detergent fiber (ADF) and acid detergent lignin (ADL)\} were also determined in the experimental rations according to Goering and Van Soest (1970). Hemicellulose was calculated as the difference between NDF and ADF, while cellulose was calculated as the difference between $\mathrm{ADF}$ and ADL.

Digestible energy (DE) was calculated according to Cheek (1987) as following:

$\mathrm{DE}(\mathrm{MJ} / \mathrm{kg} \mathrm{DM})=4.36-0.04 \times \mathrm{NDF} \%$. Non fibrous carbohydrates (NFC), calculated according to Calsamiglia et al. (1995) using the following equation:

$\mathrm{NFC}=100-\{\mathrm{CP}+\mathrm{EE}+\mathrm{Ash}+\mathrm{NDF}\}$. Diets were offered pelleted and the diameter of the pellets was $4 \mathrm{~mm}$.

Economical efficiency of experimental diets was calculated according to the local market price of ingredients and rabbit live body weight as following:

Net revenue $=$ total revenue - total feed cost. Economical efficiency $(\%)=$ net revenue/ total feed cost $\%$. Collected data were subjected to statistical analysis as two factors-factorial analysis of variance using the general linear model procedure of SPSS (1998). Duncan's Multiple Range Test (1955) was used to separate means when the dietary treatment effect was significant.

\section{Results and discussion}

\subsection{Chemical analysis and cell wall constituents of the experimental diets}

Digestible energy for six tested rations (G1-G6) was 2.516, 2.512, 2.507, 2.254, 2.252 and 2.256 (MJ/ kg DM), respectively (Table 2). These variations were related to differ in ingredients that used in ration formulations. The $90 \%$ of energy level showed slightly increase in NDF, ADF, ADL and hemicellulose contents as well as cellulose content of experimental rations showed approximately the same trend (Table 2).

\subsection{Nutrient digestibility and nutritive values of the experimental diets}

Either $100 \%$ or $90 \%$ of energy level showed insignificant effects $(\mathrm{P}>0.05)$ on OM, CP and NFE digestibility and TDN value (Table 3$)$. Lesser galangal as feed additives at $0.5 \%$ or $1 \%$ significantly $(\mathrm{P}>0.05)$ increased the $\mathrm{DM}, \mathrm{OM}, \mathrm{CF}$, NFE digestibility's and TDN value, while showed insignificant effects on $\mathrm{CP}$ and EE digestibility's and DCP value (Table 3). These significant improvements may be due to the hard fiber nature of branched pieces of powdered rhizome are from 1.5 to 3 inches in length, and seldom more than 0.75 inch thick as noticed by (Srividya et al., 2010).

The $90 \%$ energy level significantly improved $(\mathrm{P}<0.05)$ the DM and CF digestibility while EE digestibility was significantly $(\mathrm{P}<0.05)$ decreased (Table 3$)$. This significant improved in $\mathrm{DM}$ and $\mathrm{CF}$ at the lesser energy level indicated that decreasing the dietary energy level be against the level of fiber which leads to improve the properties of digestion of rabbits. Similar results obtained in rabbit by (Gidenne 1992), who reported that adaptation to a high-fibre diet resulted in a higher digestive volume for colon and caecum, related to an improved degradation of cell wall. Furthermore, digestive efficiency in the small intestine appeared higher for rabbits adapted to a high-fibre diet than that for rabbits initially fed on a low-fibre diet. 
There were significant $(\mathrm{P}<0.05)$ interaction between the energy and lesser galangal levels on digestibility coefficient of DM, OM, CF, EE, NFE and TDN value (Table 4). These significant coefficient may be due to the diarylheptanoids isolated from the rhizome of (AO) inhibitors of nitric oxide production in lip polysaccharide (Lee et al., 2006).On other hand may be due to the antibacterial effect of lesser galangal, as shown by (Eumkeb et al., 2010) who said that galangin caused damage to the ultra structures of the cells of penicillinase and $\beta$-lactamase penicillinase and $\beta$-lactamase strain.

However, it had no significant effect on CP digestibility and DCP value, rabbits that received $100 \%$ energy requirement $+0.5 \%$ lesser galangal $\left(\mathrm{G}_{2}\right)$ showed that the best digestion coefficients of $\mathrm{CP}, \mathrm{EE}, \mathrm{NFE}$ and nutritive values TDN and DCP (Table 4). This may be due to the completely covered energy requirement of rabbit. On the other hand rabbits received $90 \%$ energy requirement $+1 \%$ lesser galangal $\left(\mathrm{G}_{6}\right)$ recorded the best $\mathrm{DM}, \mathrm{OM}$ and $\mathrm{CF}$ digestibility. This may be due to the moderate potent antimicrobial activity of lesser galangal against the Bacillus cereus, Staphylococcus aureas, Pseudomonas auroginosa and Escherichia coli (Srividya et al., 2010), or may be due to the ability of lesser galangal on enhancing insulin sensitivity (Talpur et al., 2005).

\subsection{Growth performance of the experimental groups}

The energy levels showed insignificant effect on final weight, total body weight gain, ADG (g); feed intake as $\mathrm{DM}$, TDN, CP, and DCP, (g/day) and feed conversion (g intake /g gain) of DM, TDN, CP and DCP, respectively (Table 5). Lesser galangal supplementation at $0.5 \%$ or $1 \%$ significantly increased final body weight gain, ADG, feed conversion, while slightly decreased feed intake. These significant increases may be due to the damage repairing effect in digestive tract as reporting by (Purnak et al., 2010) who reported that, (AO) is considered adjunctive drug for treated acute gastrointestinal bleeding case with a low platelet count and defective hemostasis.

Addition of Lesser galangal at $1 \%$ significantly $(\mathrm{P}<0.05)$ improved the final body weight gain by $(2.31 \%)$, and average daily gain by $(2.54 \%)$ compared to the control group. This significant increased in body weight may be due to the lesser galangal pleasantly aromatic and mildly spicy taste, and is suitable for all conditions where the central areas of the body need greater warmth, as noticed by (Srividya et al., 2010).

There were no interactions between energy and lesser galangal levels (Table 6). The $90 \%$ energy with $1 \%$ lesser galangal $\left(\mathrm{G}_{6}\right)$ recorded the best values of final body weight, body weight gain, and average daily gain as well as feed conversion. These best values may be due to the hypolipidemic activity of (AO) is due to the inhibition of pancreatic lipase. Similar result obtained by (Shin et al., 2003).

\subsection{Carcass characteristics of the experimental groups}

Both energy and lesser galangal levels had no significant effect $(\mathrm{P}>0.05)$ on digestive tract, carcass cuts and chemical analysis of the 9,10 and $11^{\text {th }}$ ribs (Table 7).

There were insignificant interaction values between energy and lesser galangal levels on digestive tract empty body weight, edible offal's and chemical analysis of the 9,10 and $11^{\text {th }}$ ribs (Table 8 ). The $90 \%$ energy and $1 \%$ lesser galangal $\left(\mathrm{G}_{6}\right)$ recorded the best values of carcass weight, dressing percentages and carcass cuts. These best values may be due to the effective of lesser galangal as hypolipidemic agents (Shin et al., 2004).

The significant $(\mathrm{P}<0.05)$ interaction may be due to the ability of lesser galangal on repairing damage protein as shown by (Tabata et al., 2009) who cleared that diarylheptanoids derived from (AO) have marked antitumor activities activity against neuroblastoma cells. In other words, may be due to its effect for dyspepsia biliary symptoms, bowel spasm and angina as reported by (Shin et al., 2003).

\subsection{External, internal offal's (Giblets) and digestive tract measurements}

The energy levels showed insignificant effect on external, internal offal's (Giblets) and digestive tract measurements (Table 9). Lesser galangal also showed insignificant effect on external offal's; internal offal's (Giblets) except for lungs (weight and \% of SW) that showed significant decreased compared to control; digestive tract except for content of stomach and empty of small intestine (weight and $\%$ of SW) were significant decreased compared to control. The significant decrease in both lungs and empty of small intestine (weight and $\%$ of SW), may be due to the inhibitory effect of fatty acid syntheses of lesser galangal as reported by (Shin et al., 2004). Similar results cleared by (Li and Tian 2003) who noted that, galangal extract can potently inhibit fatty-acid syntheses.

The interaction values between energy and lesser galangal levels showed significant increase $(\mathrm{P}<0.05)$ on liver and total internal offal's (\% of SW); lungs, full \& content of stomach and digestive tract content (weight, $g$ 
and $\%$ of SW) (Table 10). These results may be due to that galangin with anti-oxidative and free radical scavenging activities is capable of modulating enzyme activities as cleared by (Heo et al., 2001).

\subsection{Economical evaluation}

The profitability of using lesser galangal depends upon the price of tested diets and the growth performance of rabbits fed these diets (Table 11). The cost of one kg feed, (LE) was decreased by $6.92,4.42$ and $3.23 \%$ in $\mathrm{G}_{4}$, $\mathrm{G}_{5}$ and $\mathrm{G}_{6}$, respectively compared to control diet $\mathrm{G}_{1}$. This result was due to the lowered energy level by $10 \%$ as quantity which under this study was considered the expensive components in diet. The $90 \%$ energy requirements with $0.5 \%$ or $1 \%$ lesser galangal showed the high values of net revenue, economical efficiency and relative economic efficiency as well as the low value of feed cost/ $\mathrm{kg}$ live body weight (LE). This high values was due to the ability of lesser galangal in raising the ration value by improving the utilization of low energy diet as our hypothesis via enhancing pancreatic insulin sensitivity.

The $90 \%$ energy level with $0.5 \%$ lesser galangal $\left(\mathrm{G}_{5}\right)$ diet recorded the highest value of relative economic efficiency $(111.4 \%)$ and the lowest value of feed cost/ $\mathrm{kg}$ live body weight $(5.45 \mathrm{LE})$. These results are in agreement with those obtained by Ibrahim et al. (2009) who fed rabbits on two different levels of energy supplemented with herbs mixture at level of (1:1:1) of Artemisia herba-alba, Matricaria recutita L. and Chrysanthemum coronarium.

\section{Conclusion}

Lowering the dietary energy level from $100 \%$ to $90 \%$ of requirements with $0.5 \%$ lesser galangal as feed additives improved the DM, OM, CP, CF, NFE digestibility's and TDN and DCP values as well as realized the highest value of relative economic efficiency followed by the lowest value of feed cost $/ \mathrm{kg}$ live body weight. Our data suggest that $\mathrm{AO}$ can be considered as growth promoter that is effective for improving the utilization of low energy diet by lowering circulating glucose levels through enhancing insulin sensitivity.

\section{References}

A.O.A.C. (2000). Official Methods of Analysis, $17^{\text {th }}$ ed. Association of Official Analytical Chemists, Washington, D.C, USA.

Blasco, A., J. Quhayaun \& G. Masoscro. (1993). Hormonization of criteria and terminology in rabbit meat research. World Rabbits Sciences, 1: 3-10.

Boulos, I. (1983). Medicinal plants of North Africa reference Publication. Inc. proc., $2^{\text {nd }}$ Con. Fac. Vit. Me. Cairo. Univ., Cairo, Egypt (1992).

Calsamiglia, S., M.D. Stem \& Frinkins, J.L. (1995). Effects of protein source on nitrogen metabolism in continuous culture and intestinal digestion in vitro. J. Anim. Sci., 73:1819.

Cheeke, P.R. (1987). Rabbit feeding and nutrition. Academic Press.

Duncan, D.B. (1955). Multiple Rang and Multiple F-Test Biometrics, 11: 1- 42.

El-Hindawy, M.M., Tawfeek, M.L., \& Osman, S.H. (1996). Effect of some biological feed additives for different periods on Performance of broiler chick. Zagazig J. Agri. Res., 23: 773-783.

Eumkeb G, Sakdarat S, Siriwong S. (2010). Reversing $\beta$-lactam antibiotic resistance of Staphylococcus aureus with galangin from Alpinia officinarum Hance and synergism with ceftazidime. Phytomedicine, 15, 18(1):40-5.

Gidenne T. (1992). Effect of fiber level, particle size and adaptation period on digestibility and rate of passage as measured at the ileum and in the feces in the adult rabbit. Br J Nutr, 67(1):133-46.

Goering, H. K. \& Van Soest, P.J. (1970). Forge fiber analysis (apparatus, reagents, procedure and some applications). Agric. Hand book 379, USDA, Washington, and DC., USA.

Heo MY, Sohn SJ, Au WW. (2001). Anti-genotoxicity of galangin as a cancer chemo preventive agent candidate. Mutat Res, 488(2):135-50.

Ibrahim, Sh. A. M., Abedo, A.A., Omer, H.A.A. \& Ali, F.A.F. (2009). Response of growing New Zealand White rabbits to diets containing different levels of energy and mixture of some medical plants. World Journal of Agricultural Science, 5 (5) 544-551.

Kim BJ, Kim JH, Kim HP, Heo MY. (1997). Biological screening of 100 plant extracts for cosmetic use (II): anti-oxidative activity and free radical scavenging activity. Int J Cosmet Sci., 19(6):299-307.

Li, BH. \& Tian, WX. (2003). Presence of fatty acid syntheses inhibitors in the rhizome of Alpinia officinarum hance. J Enzyme Inhib Med Chem., Aug, 18 (4):349-56. 
Lee HJ, Kim JS, JH. (2006). Suppression of inducible nitric oxide synthase expression by diarylheptanoids from Alpinia officinarum. PlantaMed, 72(1):68-71.

Lee J, Kim KA, Jeong S, Lee S, Park HJ, Kim NJ, Lim S. (2009). Anti- inflammatory, anti-nociceptive, and anti-psychiatric effects by the rhizomes of Alpinia officinarum on complete Freund's adjuvant-induced arthritis in rats. J Ethnopharmacol, 12, 126(2):258-64.

Lee YS, Kang OH, Cho JG, 5Oh YC, Chae HS, Kim JH, Park H, Sohn DH, Wang ZT. (2008). Synergistic effects of the combination of galangin with gentamicin against methicillin-resistant Staphylococcus aureus. $J$ Microbiol, 46(3):283-8.

Lu YH, Lin-Tao, Wang ZT, Wei DZ, Xiang HB. (2007). Mechanism and inhibitory effect of galangin and its flavonoid mixture from Alpinia officinarum on mushroom tyrosinase and B16 murine melanoma cells. $J$ Enzyme Inhib Med Chem, 22(4):433-8.

N.R.C. (1977). National Research Council. Nutrient requirements of rabbits, National Academy of Science, Washington, D.C.

O'Mary, C.C., L.M. Everett \& A.D. Graig (1979). Production and carcass characteristics of Angus and Charolais x Angus steers. J. Anim. Sci., 48: 239.

Purnak T, Ozaslan E, Beyazit Y, Haznedaroglu IC. (2010). Upper Gastrointestinal Bleeding in a Patient With Defective Hemostasis Successfully Treated with Ankaferd Blood Stopper. Phytother Res.

Sawamura R, Sun Y, Yasukawa K, Shimizu T, Watanabe W, Kurokawa M. (2010). Antiviral activities of diarylheptanoids against influenza virus in vitro. $J$ Nat Med., 64(1):117-20.

Shin JE, Han MJ, Song MC, Baek NI, Kim DH. (2004). 5-Hydroxy-7-(4'-hydroxy-3'-methoxyphenyl)-1-phenyl-3-heptanone: a pancreatic lipase inhibitor isolated from Alpinia officinarum. Biol Pharm Bull, 27(1):138-40.

Shin JE, Joo Han M, Kim DH. (2003). 3-Methylethergalangin isolated from Alpinia officinarum inhibits pancreatic lipase. Biol Pharm Bull, 26(6):854-7.

SPSS, (1998). Statistical package for Social Sciences, Chicago, U.S.A.

Srividya AR, Dhanabal SP, Misra VK, Suja G. (2010). Antioxidant and Antimicrobial Activity of Alpinia officinarum. Indian J Pharm Sci., 2010 Jan, 72(1):145-8.

Subramanian K, Selvakkumar C, Vinaykumar KS, Goswami N, Meenakshisundaram S, Balakrishnan A, Lakshmi BS. (2009). Tackling multiple antibiotic resistance in enteropathogenic Escherichia coli (EPEC) clinical isolates: a diarylheptanoid from Alpinia officinarum shows promising antibacterial and immunomodulatory activity against EPEC and its lipopolysaccharide-induced inflammation. Int J Antimicrob Agents, 33(3):244-50.

Tabata K, Yamazaki Y, Okada M, Fukumura K, Shimada A, Sun Y, Yasukawa K, Suzuki T. (2009). Diarylheptanoids derived from Alpinia officinarum induce apoptosis, S-phase arrest and differentiation in human neuroblastoma cells. Anticancer Res, 29(12):4981-8.

Talpur, N, Echard, B, Ingram, C, Bagchi, D, \& Preuss, H. (2005). Effect of a novel formulation of essential oils on glucose-insulin metabolism in diabetic and hypertensive rats: a pilot study. Diabetes Obes Metab, 3, 7 (2):193-199.

Yadav PN, Liu Z, Rafi MM. (2003). A diarylheptanoid from lesser galangal (Alpinia officinarum) inhibits proinflammatory mediators via inhibition of mitogen activated protein kinase, p44/42, and transcription factor nuclear factor-kappa B. J Pharmacol Exp Ther, 305(3):925-31.

Zhang BB, Dai Y, Liao ZX, Ding LS. (2010). Three new antibacterial active diarylheptanoids from Alpinia officinarum. Fitoterapia, 81(7):948-52. 
Table 1. Composition of the experimental diets $(\mathrm{kg} / \mathrm{ton})$

\begin{tabular}{|l|c|c|c|c|c|c|}
\hline \multirow{2}{*}{ Item } & \multicolumn{3}{|c|}{$100 \%$} & \multicolumn{3}{c|}{$90 \%$} \\
\cline { 2 - 7 } & $\mathrm{G}_{1}$ & $\mathrm{G}_{2}$ & $\mathrm{G}_{3}$ & $\mathrm{G}_{4}$ & $\mathrm{G}_{5}$ & $\mathrm{G}_{6}$ \\
\hline Yellow corn & 190.00 & 190.00 & 190.00 & ---- & --- & ---- \\
Barley grain & 100.00 & 100.00 & 100.00 & 100.00 & 100.00 & 100.00 \\
Wheat bran & 185.00 & 185.00 & 185.00 & 300.00 & 300.00 & 300.00 \\
Soybean meal 44\% CP & 150.00 & 150.00 & 150.00 & 115.00 & 115.00 & 115.00 \\
Alfalfa hay & 350.00 & 350.00 & 350.00 & 460.00 & 460.00 & 460.00 \\
Vit. \& Min. mixture* & 3.00 & 3.00 & 3.00 & 3.00 & 3.00 & 3.00 \\
Sodium chloride & 5.00 & 5.00 & 5.00 & 5.00 & 5.00 & 5.00 \\
DL-Methionine & 4.00 & 4.00 & 4.00 & 5.00 & 5.00 & 4.00 \\
Anti fungal agent & 4.00 & 4.00 & 3.00 & 4.00 & 4.00 & 3.00 \\
Bone meal & 9.00 & 4.00 & ---- & 8.00 & 3.00 & ---- \\
Supplement & ---- & 5.00 & 10.00 & ---- & 5.00 & 10.00 \\
\hline Price, L.E / Ton & 2197 & 2252 & 2298 & 2045 & 2100 & 2126 \\
\hline
\end{tabular}

* Vit. \& Min. mixture: Each kilogram of Vit. \& Min. mixture contains: 2000.000 IU Vit. A, 150.000 IU Vita. D, $8.33 \mathrm{~g}$ Vit. E, $0.33 \mathrm{~g}$ Vit. K, $0.33 \mathrm{~g}$ Vit. B1, $1.0 \mathrm{~g}$ Vit. B2, $0.33 \mathrm{~g}$ Vit. B6, $8.33 \mathrm{~g}$ Vit.B5, $1.7 \mathrm{mg}$ Vit. B12, $3.33 \mathrm{~g}$ Pantothenic acid, $33 \mathrm{mg}$ Biotin, 0.83g Folic acid, $200 \mathrm{~g}$ Choline chloride, $11.7 \mathrm{~g} \mathrm{Zn,} 12.5 \mathrm{~g} \mathrm{Fe}, 16.6 \mathrm{mg} \mathrm{Se}, 16.6$ $\mathrm{mg} \mathrm{Co}, 66.7 \mathrm{~g} \mathrm{Mg}$ and $5 \mathrm{~g} \mathrm{Mn}$.

Table 2. Chemical analysis and cell wall constituents of the experimental diets

\begin{tabular}{|l|c|c|c|c|c|c|}
\hline \multirow{2}{*}{ Item } & \multicolumn{3}{|c|}{$100 \%$} & \multicolumn{3}{c|}{$90 \%$} \\
\cline { 2 - 7 } & $\mathrm{G}_{1}$ & $\mathrm{G}_{2}$ & $\mathrm{G}_{3}$ & $\mathrm{G}_{4}$ & $\mathrm{G}_{5}$ & $\mathrm{G}_{6}$ \\
\hline Dry matter & 91.18 & 91.47 & 92.65 & 92.34 & 92.39 & 92.47 \\
Organic matter & 89.93 & 90.02 & 88.94 & 88.51 & 88.61 & 89.29 \\
Crude protein & 16.86 & 16.91 & 16.81 & 16.67 & 16.73 & 16.59 \\
Crude fiber & 13.18 & 13.57 & 13.47 & 14.29 & 14.21 & 14.19 \\
Ether extract & 4.09 & 4.02 & 3.97 & 3.89 & 3.75 & 3.68 \\
Nitrogen free extract & 55.80 & 55.52 & 54.69 & 53.66 & 53.92 & 54.83 \\
Ash & 10.07 & 9.98 & 11.06 & 11.49 & 11.39 & 10.71 \\
NFC* & 22.87 & 22.88 & 21.83 & 15.31 & 15.43 & 16.42 \\
DE (MJ/kg DM) & 2.516 & 2.512 & 2.507 & 2.254 & 2.252 & 2.256 \\
Cell wall constituents & & & & & & \\
NDF & 46.11 & 46.21 & 46.33 & 52.64 & 52.70 & 52.60 \\
ADF & 18.30 & 18.42 & 18.51 & 20.02 & 19.93 & 19.85 \\
ADL & 6.28 & 6.33 & 6.44 & 7.43 & 7.65 & 7.82 \\
Hemicellulose & 27.81 & 27.79 & 27.82 & 32.62 & 32.77 & 32.75 \\
Cellulose & 12.02 & 12.09 & 12.07 & 12.59 & 12.28 & 12.03 \\
\hline
\end{tabular}

Digestible energy (DE) was calculated as following equation: $D E(M J / \mathrm{kg} D M)=4.36-0.04 \times N D F \%$.

NDF: Neutral detergent fiber. ADF: Acid detergent fiber. ADL: Acid detergent lignin.

Hemicellulose $=N D F-A D F$. Cellulose $=A D F-A D L$.

* Non fibrous carbohydrates (NFC), calculated using the following equation:

$N F C=100-\{C P+E E+A s h+N D F\}$. 
Table 3. Effect of energy and supplementation levels on digestibility coefficients and nutritive values

\begin{tabular}{|c|c|c|c|c|c|c|c|}
\hline \multirow{3}{*}{ Item } & \multicolumn{6}{|c|}{ Experimental diets } & \multirow{3}{*}{ SEM } \\
\hline & \multicolumn{2}{|c|}{ Energy levels } & \multirow[t]{2}{*}{ SEM } & \multicolumn{3}{|c|}{ Supplementation } & \\
\hline & $100 \%$ & $90 \%$ & & $0 \%$ & $0.5 \%$ & $1 \%$ & \\
\hline \multicolumn{8}{|c|}{ Digestibility coefficients } \\
\hline 0 & $79.45^{b}$ & $83.62^{\mathrm{a}}$ & & .12 & 00. & 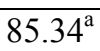 & 1.23 \\
\hline & & & & $72.45^{\mathrm{b}}$ & 77. & 77. & 0.77 \\
\hline & & & & 0.21 & & & 0.57 \\
\hline & 47.4 & $54.57^{\mathrm{a}}$ & 1.9 & $42.21^{\mathrm{b}}$ & $54.11^{\mathrm{a}}$ & $56.63^{\mathrm{a}}$ & 1.9 \\
\hline & $94.82^{\mathrm{a}}$ & $91.35^{\mathrm{b}}$ & 0.7 & 93.91 & 92.47 & 92.87 & 0.71 \\
\hline NFE & 78.94 & 78.71 & 0.75 & $76.01^{\mathrm{b}}$ & $80.64^{\mathrm{a}}$ & $79.82^{\mathrm{a}}$ & 0.7 \\
\hline \multicolumn{8}{|c|}{ values } \\
\hline & 723 & 17 & 0 . & $69.33^{b}$ & $73.68^{\mathrm{a}}$ & $73.24^{\mathrm{a}}$ & 0.70 \\
\hline $\mathrm{CP} 0$ & 3.74 & 13.64 & 0.10 & 13.46 & 13.93 & 13.69 & 0.10 \\
\hline
\end{tabular}

$a$ and $b$ : Means in the same row within each treatment having different superscripts differ significantly $(P<0.05)$.

SEM, standard error of the mean.

Table 4. Effect of interactions between energy and supplementation levels on digestibility coefficients and nutritive values

\begin{tabular}{|c|c|c|c|c|c|c|c|}
\hline \multirow[b]{3}{*}{ Item } & \multicolumn{6}{|c|}{ Experimental diets } & \multirow[b]{3}{*}{ SEM } \\
\hline & \multicolumn{3}{|c|}{$\begin{array}{c}100 \% \\
\text { Energy requirements }\end{array}$} & \multicolumn{3}{|c|}{$\begin{array}{c}90 \% \\
\text { Energy requirements }\end{array}$} & \\
\hline & $\mathrm{G}_{1}$ & $\mathrm{G}_{2}$ & $\mathrm{G}_{3}$ & $\mathrm{G}_{4}$ & $\mathrm{G}_{5}$ & $\mathrm{G}_{6}$ & \\
\hline \multicolumn{8}{|c|}{ Digestibility coefficients } \\
\hline DM & $79.86^{b}$ & $79.00^{b}$ & $79.49^{b}$ & $77.59^{b}$ & $82.09^{b}$ & $91.18^{\mathrm{a}}$ & 1.23 \\
\hline $\mathrm{OM}$ & $72.06^{\mathrm{c}}$ & $77.90^{\mathrm{a}}$ & $76.33^{\mathrm{abc}}$ & $72.85^{\mathrm{bc}}$ & $77.01^{\mathrm{ab}}$ & $78.05^{\mathrm{a}}$ & 0.77 \\
\hline $\mathrm{CP}$ & 79.58 & 83.11 & 81.74 & 80.97 & 82.51 & 82.16 & 0.57 \\
\hline $\mathrm{CF}$ & $36.86^{\mathrm{d}}$ & $51.59^{\mathrm{bc}}$ & $53.76^{\mathrm{abc}}$ & $47.56^{\mathrm{d}}$ & $56.63^{\mathrm{ab}}$ & $59.51^{\mathrm{a}}$ & 1.93 \\
\hline EE & $96.80^{\mathrm{a}}$ & $95.03^{\mathrm{ab}}$ & $92.64^{\mathrm{bc}}$ & $91.02^{\mathrm{c}}$ & $89.91^{\mathrm{c}}$ & $93.11^{\mathrm{a}}$ & 0.71 \\
\hline NFE & $76.28^{\mathrm{b}}$ & $81.49^{\mathrm{a}}$ & $79.05^{\mathrm{ab}}$ & $75.74^{\mathrm{b}}$ & $79.79^{\mathrm{ab}}$ & $80.60^{\mathrm{ab}}$ & 0.75 \\
\hline \multicolumn{8}{|c|}{ Nutritive values } \\
\hline TDI & $69.75^{\mathrm{b}}$ & $74.89^{\mathrm{a}}$ & $72.50^{\mathrm{ab}}$ & $68.91^{\mathrm{b}}$ & $72.47^{\mathrm{ab}}$ & $73.98^{\mathrm{a}}$ & 0.70 \\
\hline DCP\% & 13.14 & 14.05 & 13.74 & 13.50 & 13.80 & 13.63 & 0.10 \\
\hline
\end{tabular}

$a, b, c$ and $d$ : Means in the same row having different superscripts differ significantly $(P<0.05)$.SEM, standard error of the mean.

Table 5. Effect of energy and supplementation levels on growth performance of the experimental groups

\begin{tabular}{|c|c|c|c|c|c|c|c|}
\hline \multirow{3}{*}{ Item } & \multicolumn{6}{|c|}{ Experimental diets } & \multirow{3}{*}{ SEM } \\
\hline & \multicolumn{2}{|c|}{ Energy levels } & \multirow[t]{2}{*}{ SEM } & \multicolumn{3}{|c|}{ Supplementation } & \\
\hline & $100 \%$ & $90 \%$ & & $0 \%$ & $1 \%$ & $2 \%$ & \\
\hline Initial weight, $\mathrm{g}$ & 406 & 411 & 4.92 & 413 & 411 & 401 & 4.92 \\
\hline Final weight, $\mathrm{g}$ & 2416 & 2433 & 7.09 & 2403 & 2432 & 2437 & 7.09 \\
\hline Gain, $g$ & 2010 & 2022 & 8.21 & $1990^{\mathrm{b}}$ & $2021^{\mathrm{ab}}$ & $2036^{\mathrm{a}}$ & 8.21 \\
\hline ADG, $g$ & 35.9 & 36.1 & 0.15 & $35.5^{\mathrm{b}}$ & $36.1^{\mathrm{ab}}$ & $36.4^{\mathrm{a}}$ & 0.15 \\
\hline \multicolumn{8}{|l|}{ Feed intake as: } \\
\hline DM, g/day & 104.04 & 107.90 & 4.83 & 109.10 & 104.25 & 105.10 & 4.83 \\
\hline TDN, g/day & 75.57 & 77.36 & 3.47 & 75.62 & 76.81 & 76.97 & 3.47 \\
\hline $\mathrm{CP}, \mathrm{g} /$ day & 17.60 & 17.98 & 0.81 & 18.28 & 17.53 & 17.55 & 0.81 \\
\hline DCP, g/day & 14.21 & 14.72 & 0.66 & 14.49 & 14.52 & 14.38 & 0.66 \\
\hline \multicolumn{8}{|c|}{ Feed conversion (g intake /g gain) of } \\
\hline DM & 2.91 & 2.99 & 0.13 & 3.07 & 2.89 & 2.89 & 0.13 \\
\hline TDN & 2.11 & 2.14 & 0.10 & 2.13 & 2.13 & 2.12 & 0.10 \\
\hline CP & 0.49 & 0.50 & 0.02 & 0.52 & 0.49 & 0.48 & 0.02 \\
\hline DCP & 0.40 & 0.41 & 0.02 & 0.41 & 0.40 & 0.39 & 0.02 \\
\hline
\end{tabular}

$a$ and $b$ : Means in the same row within each treatment having different superscripts differ significantly $(P<0.05)$. SEM, standard error of the mean. 
Table 6. Effect of interactions between energy and supplementation levels on growth performance of the experimental groups

\begin{tabular}{|c|c|c|c|c|c|c|c|}
\hline \multirow{3}{*}{ Item } & \multicolumn{6}{|c|}{ Experimental diets } & \multirow{3}{*}{ SEM } \\
\hline & \multicolumn{3}{|c|}{$\begin{array}{c}100 \% \\
\text { Energy requirements }\end{array}$} & \multicolumn{3}{|c|}{$\begin{array}{c}90 \% \\
\text { Energy requirements }\end{array}$} & \\
\hline & $\mathrm{G}_{1}$ & $\mathrm{G}_{2}$ & $\mathrm{G}_{3}$ & $\mathrm{G}_{4}$ & $\mathrm{G}_{5}$ & $\mathrm{G}_{6}$ & \\
\hline Initial weight, $\mathrm{g}$ & 411 & 409 & 398 & 416 & 413 & 404 & 4.92 \\
\hline Final weight, g & 2396 & 2424 & 2427 & 2411 & 2440 & 2449 & 7.09 \\
\hline Gain, $g$ & 1985 & 2015 & 2029 & 1995 & 2027 & 2045 & 8.21 \\
\hline ADG, $g$ & 35.4 & 36.0 & 36.2 & 35.6 & 36.2 & 36.5 & 0.15 \\
\hline \multicolumn{8}{|l|}{ Feed intake as: } \\
\hline $\mathrm{DM}, \mathrm{g} / \mathrm{day}$ & 103.80 & 104.00 & 105.44 & 114.41 & 104.49 & 104.77 & 4.83 \\
\hline TDN, g/day & 72.40 & 77.89 & 76.44 & 78.84 & 75.72 & 77.51 & 3.47 \\
\hline $\mathrm{CP}, \mathrm{g} / \mathrm{day}$ & 17.50 & 17.59 & 17.72 & 19.07 & 17.48 & 17.38 & 0.81 \\
\hline DCP, g/day & 13.92 & 14.61 & 14.49 & 15.45 & 14.42 & 14.28 & 0.66 \\
\hline \multicolumn{8}{|c|}{ Feed conversion (g intake /g gain) of } \\
\hline $\mathrm{DM}$ & 2.93 & 2.89 & 2.91 & 3.21 & 2.89 & 2.87 & 0.13 \\
\hline TDN & 2.05 & 2.16 & 2.11 & 2.21 & 2.09 & 2.12 & 0.10 \\
\hline $\mathrm{CP}$ & 0.49 & 0.49 & 0.49 & 0.54 & 0.48 & 0.48 & 0.02 \\
\hline DCP & 0.39 & 0.41 & 0.40 & 0.43 & 0.40 & 0.39 & 0.02 \\
\hline
\end{tabular}

$S E M$, standard error of the mean.

Table 7. Effects of energy and supplementation levels on dressing percentages, carcass cuts and chemical analysis of the 9,10 and $11^{\text {th }}$ ribs of the experimental groups

\begin{tabular}{|c|c|c|c|c|c|c|c|}
\hline \multirow{3}{*}{ Item } & \multicolumn{6}{|c|}{ Experimental diets } & \multirow{3}{*}{ SEM } \\
\hline & \multicolumn{2}{|c|}{ Energy levels } & \multirow[t]{2}{*}{ SEM } & \multicolumn{3}{|c|}{ Supplementation } & \\
\hline & $100 \%$ & $90 \%$ & & $0 \%$ & $1 \%$ & $2 \%$ & \\
\hline \multicolumn{8}{|l|}{$\begin{array}{l}\text { Slaughter weight (SW), } g \\
\text { Digestive tract } g\end{array}$} \\
\hline $\begin{array}{l}\text { Digestive tract, } g \\
\text { Full }\end{array}$ & 386 & 361 & 12.42 & 379 & 369 & 373 & 12.42 \\
\hline Empty & 141 & 130 & 5.28 & 126 & 142 & 138 & 5.28 \\
\hline Content & 235 & 231 & 10.10 & 253 & 227 & 235 & 10.10 \\
\hline Empty body weight (EBW), g & 2216 & 2218 & 9.86 & 2214 & 2213 & 2208 & 9.86 \\
\hline Edible offal's, g (Giblets) & 123 & 130 & 8.47 & 116 & 135 & 128 & 8.47 \\
\hline Carcass weight (CW), g & 1126 & 1132 & 13.00 & 1104 & 1132 & 1151 & 13.00 \\
\hline Carcass weight* & 1249 & 1262 & 9.97 & 1210 & 1267 & 1279 & 9.97 \\
\hline \multicolumn{8}{|l|}{ Dressing percentages $(D P) \%$} \\
\hline DP & 45.92 & 46.24 & 0.54 & 44.77 & 46.38 & 47.11 & 0.54 \\
\hline $\mathrm{DP}^{2}$ & 50.78 & 51.06 & 0.52 & 49.97 & 51.13 & 51.74 & 0.52 \\
\hline $\mathrm{DP}^{3}$ & 56.97 & 56.92 & 0.41 & 56.08 & 57.25 & 57.50 & 0.41 \\
\hline \multicolumn{8}{|l|}{ Carcass cuts } \\
\hline \multicolumn{8}{|l|}{ Fore part } \\
\hline Weigl & 389 & 390 & 4.95 & 382 & 390 & 397 & 4.95 \\
\hline$\%$ of $\mathrm{CW}$ & 34.55 & 34.44 & 0.09 & 34.55 & 34.47 & 34.46 & 0.09 \\
\hline \multicolumn{8}{|l|}{ Middle part } \\
\hline Weight, $g$ & 237 & 238 & 3.02 & 232 & 239 & 241 & 3.02 \\
\hline$\%$ of $\mathrm{CW}$ & 21.03 & 21.02 & 0.16 & 21.08 & 21.04 & 20.94 & 0.16 \\
\hline \multicolumn{8}{|l|}{ Hind part } \\
\hline Weight, $g$ & 500 & 504 & 5.86 & 490 & 503 & 513 & 5.86 \\
\hline$\%$ of CW & 44.42 & 44.54 & 0.12 & 44.37 & 44.49 & 44.60 & 0.12 \\
\hline \multicolumn{8}{|c|}{ Chemical analysis of the 9,10 and $11^{\text {th }}$ ribs } \\
\hline Dry matter & 33.58 & 32.75 & 0.90 & 32.14 & 33.17 & 34.18 & 0.90 \\
\hline \multicolumn{8}{|c|}{ Chemical composition on DM basis } \\
\hline $\mathrm{CP}$ & 55.62 & 62.28 & 1.76 & 59.69 & 58.45 & 58.71 & 1.76 \\
\hline $\mathrm{EE}$ & 36.95 & 29.51 & 1.97 & 32.02 & 33.96 & 33.71 & 1.97 \\
\hline Ash & 7.43 & 8.21 & 0.29 & 8.29 & 7.60 & 7.58 & 0.29 \\
\hline
\end{tabular}

* Carcass weight: included edible offal's (Liver, heart, kidneys, lungs, spleen and testes).

DP 1 : Dressing percentages calculated as (carcass weight / slaughter weight).

DP 2 : Dressing percentages calculated as (carcass weight / empty body weight).

DP 3 : Dressing percentages calculated as (carcass weight + edible offal's / empty body weight)

EBW: Empty body weight $=$ Slaughter weight - digestive tract content.. 
Table 8. Effect of interactions between energy and supplementation levels on dressing percentages, carcass cuts and chemical analysis of the 9,10 and $11^{\text {th }}$ ribs of the experimental groups

\begin{tabular}{|c|c|c|c|c|c|c|c|}
\hline \multirow[b]{3}{*}{ Item } & \multicolumn{6}{|c|}{ Experimental diets } & \multirow[b]{3}{*}{ SEM } \\
\hline & \multicolumn{3}{|c|}{$\begin{array}{c}100 \% \\
\text { Energy requirements }\end{array}$} & \multicolumn{3}{|c|}{$\begin{array}{c}90 \% \\
\text { Energy requirements }\end{array}$} & \\
\hline & $\mathrm{G}_{1}$ & $\mathrm{G}_{2}$ & $\mathrm{G}_{3}$ & $\mathrm{G}_{4}$ & $\mathrm{G}_{5}$ & $\mathrm{G}_{6}$ & \\
\hline Slaughter weight (SW), g & 2467 & 2440 & 2447 & 2467 & 2440 & 2440 & 5.42 \\
\hline \multicolumn{8}{|l|}{ Digestive tract, $g$} \\
\hline Full & 354 & 390 & 381 & 403 & 348 & 331 & 12.42 \\
\hline Empty & 125 & 159 & 139 & 127 & 125 & 137 & 5.28 \\
\hline Content & 229 & 231 & 242 & 276 & 223 & 194 & 10.10 \\
\hline Empty body weight (EBW), g & 2238 & 2209 & 2204 & 2190 & 2217 & 2246 & 9.86 \\
\hline Edible offal's, g (Giblets) & 131 & 136 & 144 & 144 & 134 & 112 & 8.47 \\
\hline Carcass weight $(\mathrm{CW}), \mathrm{g}$ & $1129^{\mathrm{abc}}$ & $1149^{\mathrm{ab}}$ & $1099^{\mathrm{bc}}$ & $1080^{\mathrm{c}}$ & $1114^{\mathrm{bc}}$ & $1203^{\mathrm{a}}$ & 13.00 \\
\hline Carcass weight* & 1260 & 1285 & 1243 & 1223 & 1248 & 1315 & 9.97 \\
\hline \multicolumn{8}{|l|}{ Dressing percentages $(D P) \%$} \\
\hline $\mathrm{DP}^{l}$ & $45.76^{\mathrm{bc}}$ & $47.09^{\mathrm{ab}}$ & $44.91^{\mathrm{bc}}$ & $43.78^{c}$ & $45.66^{\mathrm{bc}}$ & $49.30^{\mathrm{a}}$ & 0.54 \\
\hline $\mathrm{DP}^{2}$ & $50.45^{\mathrm{ab}}$ & $52.01^{\mathrm{ab}}$ & $49.86^{\mathrm{b}}$ & $49.32^{\mathrm{b}}$ & $50.25^{\mathrm{ab}}$ & $53.56^{\mathrm{a}}$ & 0.52 \\
\hline $\mathrm{DP}^{3}$ & 56.30 & 58.17 & 56.40 & 55.84 & 56.29 & 58.55 & 0.41 \\
\hline \multicolumn{8}{|l|}{ Carcass cuts } \\
\hline \multicolumn{8}{|l|}{ Fore part } \\
\hline Weight, $g$ & $393^{\mathrm{ab}}$ & $397^{\mathrm{ab}}$ & $377^{\mathrm{b}}$ & $370^{\mathrm{b}}$ & $383^{\mathrm{ab}}$ & $417^{\mathrm{a}}$ & 4.95 \\
\hline$\%$ of $\mathrm{CW}$ & $34.84^{\mathrm{ab}}$ & $34.51^{\mathrm{ab}}$ & $34.27^{\mathrm{b}}$ & $34.27^{\mathrm{b}}$ & $34.40^{\mathrm{b}}$ & $34.65^{\mathrm{a}}$ & 0.09 \\
\hline \multicolumn{8}{|l|}{ Middle part } \\
\hline Weight, $g$ & 236 & 242 & 232 & 230 & 234 & 250 & 3.02 \\
\hline$\%$ of $\mathrm{CW}$ & 20.87 & 21.08 & 21.15 & 21.28 & 21.04 & 20.74 & 0.16 \\
\hline \multicolumn{8}{|l|}{ Hind part } \\
\hline Weight, g & $500^{\mathrm{b}}$ & $510^{\mathrm{ab}}$ & $490^{\mathrm{b}}$ & $480^{\mathrm{b}}$ & $497^{\mathrm{b}}$ & $536^{\mathrm{a}}$ & 5.86 \\
\hline$\%$ of $\mathrm{CW}$ & 44.29 & 44.41 & 44.58 & 44.45 & 44.56 & 44.61 & 0.12 \\
\hline \multicolumn{8}{|c|}{ Chemical analysis of the 9,10 and $11^{\text {th }}$ ribs } \\
\hline Dry matter & 33.45 & 33.38 & 33.91 & 30.82 & 32.96 & 34.46 & 0.90 \\
\hline \multicolumn{8}{|c|}{ Chemical composition on DM basis } \\
\hline $\mathrm{CP}$ & 54.75 & 56.95 & 55.17 & 64.64 & 59.94 & 62.25 & 1.76 \\
\hline $\mathrm{EE}$ & 37.42 & 35.99 & 37.44 & 26.61 & 31.93 & 29.99 & 1.97 \\
\hline Ash & 7.83 & 7.06 & 7.39 & 8.75 & 8.13 & 7.76 & 0.29 \\
\hline
\end{tabular}

* Carcass weight: included edible offal's (Liver, heart, kidneys, lungs, spleen and testes).

$D P^{1}$ : Dressing percentages calculated as (carcass weight / slaughter weight).

$D P^{2}$ : Dressing percentages calculated as (carcass weight / empty body weight).

$D P^{3}$ : Dressing percentages calculated as ( carcass weight + edible offal's / empty body weight)

$E B W$ : Empty body weight $=$ Slaughter weight - digestive tract content.

$a, b$ and $c$ : Means in the same row having different superscripts differ significantly $(P<0.5)$. 
Table 9. Effects of energy and supplementation levels on external, internal offal's (Giblets) and digestive tract measurements of the experimental groups

\begin{tabular}{|c|c|c|c|c|c|c|c|c|}
\hline \multirow{3}{*}{ Item } & & \multicolumn{6}{|c|}{ Experimental diets } & \multirow{3}{*}{ SEM } \\
\hline & & \multicolumn{2}{|c|}{ Energy levels } & \multirow[t]{2}{*}{ SEM } & \multicolumn{3}{|c|}{ Supplementation } & \\
\hline & & $100 \%$ & $90 \%$ & & $0 \%$ & $0.5 \%$ & $1 \%$ & \\
\hline Slaughter weigh & & 2451 & 2449 & 5.42 & 2467 & 2440 & 2443 & 5.42 \\
\hline \multicolumn{2}{|l|}{ External offal's: } & & & & & & & \\
\hline & weight, g & 666 & 678 & 14.12 & 698 & 656 & 662 & 14.12 \\
\hline & $\%$ of SW & 24.94 & 27.69 & 1.15 & 24.97 & 26.87 & 27.11 & 1.15 \\
\hline \multicolumn{2}{|c|}{ Internal offal's(Giblets): } & & & & & & & \\
\hline \multirow{2}{*}{ Liver } & weight, g & 80.78 & 73.89 & 3.79 & 80.33 & 80.83 & 70.83 & 3.79 \\
\hline & $\%$ of SW & 7.22 & 6.60 & 0.38 & 7.29 & 7.21 & 6.24 & 0.38 \\
\hline \multirow[t]{2}{*}{ Heart } & weight, $\mathrm{g}$ & 10.11 & 10.33 & 0.48 & 9.33 & 10.83 & 10.50 & 0.48 \\
\hline & $\%$ of SW & 0.90 & 0.92 & 0.05 & 0.85 & 0.96 & 0.92 & 0.05 \\
\hline \multirow[t]{2}{*}{ Lungs } & weight, $g$ & 15.00 & 14.78 & 0.63 & $17.17^{\mathrm{a}}$ & $13.33^{\mathrm{b}}$ & $14.17^{\mathrm{b}}$ & 0.63 \\
\hline & $\%$ of SW & 1.34 & 1.32 & 0.06 & $1.56^{\mathrm{a}}$ & $1.18^{\mathrm{b}}$ & $1.24^{\mathrm{b}}$ & 0.06 \\
\hline \multirow[t]{2}{*}{ Kidneys } & weight, $\mathrm{g}$ & 20.67 & 20.00 & 0.82 & 19.67 & 19.67 & 21.67 & 0.82 \\
\hline & $\%$ of SW & 1.84 & 1.77 & 0.08 & 1.79 & 1.74 & 1.90 & 0.08 \\
\hline \multirow[t]{2}{*}{ Spleen } & weight, $\mathrm{g}$ & 1.22 & 1.22 & 0.10 & 1.33 & 1.00 & 1.33 & 0.10 \\
\hline & $\%$ of SW & 0.11 & 0.11 & 0.01 & 0.12 & 0.09 & 0.12 & 0.01 \\
\hline \multirow[t]{2}{*}{ Tests } & weight, $g$ & 9.33 & 8.56 & 0.53 & 9.50 & 7.67 & 9.67 & 0.53 \\
\hline & $\%$ of SW & 0.83 & 0.85 & 0.03 & 0.86 & 0.83 & 0.84 & 0.03 \\
\hline \multirow[t]{2}{*}{ Total } & weight, $g$ & 137 & 130 & 4.85 & 137 & 135 & 128 & 4.85 \\
\hline & $\%$ of SW & 12.24 & 11.57 & 0.51 & 12.46 & 12.00 & 11.26 & 0.51 \\
\hline \multicolumn{9}{|c|}{ Digestive tract measurements } \\
\hline \multicolumn{9}{|l|}{ Stomach: } \\
\hline \multirow[t]{2}{*}{ Full } & weight, $\mathrm{g}$ & 110.67 & 95.89 & 6.28 & 106.83 & 110.33 & 92.67 & 6.28 \\
\hline & $\%$ of SW & 4.52 & 3.91 & 0.26 & 4.33 & 4.52 & 3.79 & 0.26 \\
\hline \multirow[t]{2}{*}{ Empty } & weight, $g$ & 31.56 & 27.56 & 1.57 & 27.17 & 30.17 & 31.33 & 1.57 \\
\hline & $\%$ of SW & 1.29 & 1.13 & 0.07 & 1.10 & 1.24 & 1.29 & 0.07 \\
\hline Content & weight, $g$ & 79.11 & 68.33 & 5.68 & $79.67^{\mathrm{a}}$ & $80.17^{\mathrm{a}}$ & $61.33^{\mathrm{b}}$ & 5.68 \\
\hline & $\%$ of SW & 3.23 & 2.79 & 0.23 & $3.23^{\mathrm{a}}$ & $3.29^{\mathrm{a}}$ & $2.51^{\mathrm{b}}$ & 0.23 \\
\hline Small intestine: & & & & & & & & \\
\hline Full & weight, $\mathrm{g}$ & 100.00 & 103.44 & 4.56 & 97.17 & 111.33 & 96.83 & 4.56 \\
\hline & $\%$ of SW & 4.09 & 4.22 & 0.19 & 3.94 & 4.56 & 3.97 & 0.19 \\
\hline Empty & weight, $\mathrm{g}$ & 60.00 & 62.56 & 2.90 & $53.83^{\mathrm{b}}$ & $68.67^{\mathrm{a}}$ & $61.33^{\mathrm{ab}}$ & 2.90 \\
\hline & $\%$ of SW & 2.45 & 2.55 & 0.12 & $2.18^{\mathrm{b}}$ & $2.82^{\mathrm{a}}$ & $2.51 \mathrm{a}^{\mathrm{b}}$ & 0.12 \\
\hline Content & weight, $g$ & 40.11 & 40.89 & 3.48 & 43.33 & 42.67 & 35.50 & 3.48 \\
\hline & $\%$ of SW & 1.64 & 1.67 & 0.14 & 1.76 & 1.75 & 1.46 & 0.14 \\
\hline Large intestine: & & & & & & & & \\
\hline Full & weight, g & 164.11 & 161.56 & 7.94 & 174.50 & 147.50 & 166.50 & 7.94 \\
\hline & $\%$ of SW & 8.70 & 6.59 & 0.32 & 7.08 & 6.05 & 6.81 & 0.32 \\
\hline Empty & weight, $\mathrm{g}$ & 49.22 & 39.56 & 2.45 & 45.00 & 43.00 & 45.17 & 2.45 \\
\hline & $\%$ of SW & 2.01 & 1.62 & 0.10 & 1.83 & 1.76 & 1.85 & 0.10 \\
\hline Content & weight, $\mathrm{g}$ & 114.89 & 122.00 & 6.81 & 129.50 & 10.50 & 121.33 & 6.81 \\
\hline & $\%$ of SW & 4.69 & 4.98 & 0.27 & 5.25 & 4.29 & 4.96 & 0.27 \\
\hline Digestive tract: & & & & & & & & \\
\hline Full & weight, g & 374.88 & 360.88 & 12.43 & 378.50 & 369.17 & 356.00 & 12.43 \\
\hline & $\%$ of SW & 15.31 & 14.73 & 0.51 & 15.34 & 15.14 & 14.57 & 0.51 \\
\hline Empty & weight, g & 140.78 & 129.67 & 5.28 & 12.600 & 141.83 & 137.83 & 5.28 \\
\hline & $\%$ of SW & 5.75 & 5.30 & 0.22 & 5.11 & 5.82 & 5.65 & 0.22 \\
\hline Content & weight, $\mathrm{g}$ & 235.13 & 231.22 & 10.71 & 257.80 & 227.33 & 218.17 & 10.71 \\
\hline & $\%$ of SW & 9.56 & 9.43 & 0.41 & 10.24 & 9.32 & 8.92 & 0.41 \\
\hline
\end{tabular}

External offal's: included (Head, fur, legs and ears).

$a$, and $b$ : Means in the same row within each treatment having different superscripts differ significantly $(P<0.5)$. 
Table 10. Effect of interactions between energy and supplementation levels on external, internal offal's (Giblets) and digestive tract measurements of the experimental groups

\begin{tabular}{|c|c|c|c|c|c|c|c|}
\hline \multirow[b]{3}{*}{ Item } & \multicolumn{6}{|c|}{ Experimental diets } & \multirow[b]{3}{*}{ SEM } \\
\hline & \multicolumn{3}{|c|}{$\begin{array}{c}100 \% \\
\text { Energy requirements }\end{array}$} & \multicolumn{3}{|c|}{$\begin{array}{c}90 \% \\
\text { Energy requirements }\end{array}$} & \\
\hline & $\mathrm{G}_{1}$ & $\mathrm{G}_{2}$ & $\mathrm{G}_{3}$ & $\mathrm{G}_{4}$ & $\mathrm{G}_{5}$ & $\mathrm{G}_{6}$ & \\
\hline Slaughter weight (SW), g & 2467 & 2440 & 2447 & 2467 & 2440 & 2440 & 5.42 \\
\hline$\frac{\text { External offal's }}{\text { weight, g \% of SW }}$ & $\begin{array}{c}706 \\
28.63\end{array}$ & $\begin{array}{c}613 \\
24.14\end{array}$ & $\begin{array}{c}679 \\
27.75\end{array}$ & $\begin{array}{c}690 \\
27.97\end{array}$ & $\begin{array}{r}698 \\
28.62\end{array}$ & $\begin{array}{c}646 \\
26.46\end{array}$ & $\begin{array}{c}14.12 \\
1.15\end{array}$ \\
\hline Internal offal's(Giblets): & & & & & & & \\
\hline Liver weight (g) & 77.33 & 81.67 & 83.33 & 83.33 & 80.00 & 58.33 & 3.79 \\
\hline$\%$ of SW & $6.85^{\mathrm{ab}}$ & $7.23^{\mathrm{ab}}$ & $7.59^{\mathrm{ab}}$ & $7.73^{\mathrm{a}}$ & $7.19^{\mathrm{ab}}$ & $4.89^{\mathrm{b}}$ & 0.38 \\
\hline Heart weight(g) & 8.67 & 10.00 & 11.67 & 10.00 & 11.67 & 9.33 & 0.48 \\
\hline$\%$ of SW & 0.77 & 0.87 & 1.06 & 0.93 & 1.05 & 0.78 & 0.05 \\
\hline Lungs weight(g) & $16.67^{\mathrm{ab}}$ & $13.33^{\mathrm{b}}$ & $15.00^{\mathrm{ab}}$ & $17.67^{\mathrm{a}}$ & $13.33^{\mathrm{b}}$ & $13.33^{\mathrm{b}}$ & 0.63 \\
\hline$\%$ of SW & $1.48^{\mathrm{ab}}$ & $1.17^{\mathrm{b}}$ & $1.37^{\mathrm{ab}}$ & $1.64^{\mathrm{a}}$ & $1.19^{\mathrm{b}}$ & $1.12^{\mathrm{b}}$ & 0.06 \\
\hline Kidneys weight(g) & 17.67 & 21.00 & 23.33 & 21.67 & 18.33 & 20.00 & 0.82 \\
\hline$\%$ of SW & 1.56 & 1.84 & 2.12 & 2.01 & 1.64 & 1.67 & 0.08 \\
\hline Spleen weight $(\mathrm{g})$ & 1.33 & 1.00 & 1.33 & 1.33 & 1.00 & 1.33 & 0.10 \\
\hline$\%$ of SW & 0.12 & 0.09 & 0.12 & 0.12 & 0.09 & 0.11 & 0.01 \\
\hline Tests weight $(\mathrm{g})$ & 9.33 & 9.00 & 9.67 & 9.67 & 9.67 & 9.67 & 0.53 \\
\hline$\%$ of SW & 0.83 & 0.79 & 0.88 & 0.89 & 0.86 & 0.81 & 0.03 \\
\hline Total weight (g) & 131 & 136 & 144 & 144 & 134 & 112 & 4.85 \\
\hline$\%$ of SW & $11.61^{\mathrm{ab}}$ & $11.99^{\mathrm{ab}}$ & $13.14^{\mathrm{a}}$ & $13.32^{\mathrm{a}}$ & $12.02^{\mathrm{ab}}$ & $9.38^{\mathrm{b}}$ & 0.51 \\
\hline \multicolumn{8}{|c|}{ Digestive tract measurements } \\
\hline \multicolumn{8}{|l|}{ Stomach: } \\
\hline Full weight(g) & $97.33^{\mathrm{a}}$ & $110.33^{\mathrm{a}}$ & $124.33^{\mathrm{a}}$ & $116.33^{\mathrm{a}}$ & $110.33^{\mathrm{a}}$ & $61.00^{\mathrm{b}}$ & 6.28 \\
\hline$\%$ of SW & $3.95^{\mathrm{a}}$ & $4.52^{\mathrm{a}}$ & $5.08^{\mathrm{a}}$ & $4.71^{\mathrm{a}}$ & $4.52^{\mathrm{a}}$ & $2.50^{\mathrm{b}}$ & 0.26 \\
\hline Empty weight(g) & 27.33 & 34.00 & 33.33 & 27.00 & 26.33 & 29.33 & 1.57 \\
\hline$\%$ of SW & 1.11 & 1.40 & 1.37 & 1.10 & 1.08 & 1.20 & 0.07 \\
\hline Content weight(g) & $70.00^{\mathrm{a}}$ & $76.33^{\mathrm{a}}$ & $91.00^{\mathrm{a}}$ & $89.33^{\mathrm{a}}$ & $84.00^{\mathrm{a}}$ & $31.67^{b}$ & 5.68 \\
\hline$\%$ of SW & $2.84^{\mathrm{a}}$ & $3.12^{\mathrm{a}}$ & $3.71^{\mathrm{a}}$ & $3.61^{\mathrm{a}}$ & $3.44^{\mathrm{a}}$ & $1.30^{\mathrm{b}}$ & 0.23 \\
\hline \multicolumn{8}{|l|}{ Small intestine: } \\
\hline Full weight(g) & 83.33 & 115.00 & 102.00 & 111.00 & 107.67 & 91.67 & 4.56 \\
\hline$\%$ of SW & 3.37 & 4.72 & 4.17 & 4.50 & 4.41 & 3.76 & 0.19 \\
\hline Empty weight(g) & $49.33^{b}$ & $73.33^{\mathrm{a}}$ & $57.3^{\mathrm{ab}}$ & $58.3^{\mathrm{ab}}$ & $64.0^{\mathrm{ab}}$ & $65.3^{\mathrm{ab}}$ & 2.90 \\
\hline$\%$ of SW & $2.00^{\mathrm{ab}}$ & $3.01^{\mathrm{a}}$ & $2.34^{\mathrm{b}}$ & $2.36^{\mathrm{ab}}$ & $2.62^{\mathrm{ab}}$ & $2.68^{\mathrm{ab}}$ & 0.12 \\
\hline Content weight(g) & $34.00^{\mathrm{ab}}$ & $41.67^{\mathrm{ab}}$ & $44.7^{\mathrm{ab}}$ & $52.67^{\mathrm{a}}$ & 43. $7^{\mathrm{ab}}$ & $26.34^{\mathrm{b}}$ & 3.48 \\
\hline$\%$ of SW & $1.37^{\mathrm{ab}}$ & $1.71^{\mathrm{ab}}$ & $1.83^{\mathrm{ab}}$ & $2.14^{\mathrm{a}}$ & $1.79^{\mathrm{ab}}$ & $1.08^{\mathrm{b}}$ & 0.14 \\
\hline \multicolumn{8}{|l|}{ Large intestine: } \\
\hline Full weight(g) & 173.00 & 164.67 & 154.67 & 176.00 & 130.33 & 178.33 & 7.94 \\
\hline$\%$ of SW & 7.02 & 6.76 & 6.33 & 7.13 & 5.34 & 7.30 & 0.32 \\
\hline Empty weight(g) & 48.33 & 51.33 & 48.00 & 41.67 & 34.67 & 42.33 & 2.45 \\
\hline$\%$ of SW & 1.96 & 2.11 & 1.97 & 1.69 & 1.42 & 1.74 & 0.10 \\
\hline Content weight(g) & 124.67 & 113.34 & 106.67 & 134.33 & 95.66 & 136.00 & 6.81 \\
\hline$\%$ of SW & 5.06 & 4.65 & 4.36 & 5.44 & 3.92 & 5.56 & 0.27 \\
\hline \multicolumn{8}{|l|}{ Digestive tract: } \\
\hline Full weight(g) & 354.00 & 390 & 381.00 & 403.00 & 348.00 & 331.00 & 12.43 \\
\hline$\%$ of SW & 14.34 & 16.00 & 15.58 & 16.35 & 14.28 & 13.56 & 0.51 \\
\hline Empty weight(g) & 125.00 & 159.00 & 139.00 & 127.00 & 125.00 & 137.00 & 5.28 \\
\hline$\%$ of SW & 5.07 & 6.51 & 5.68 & 5.15 & 5.12 & 5.62 & 0.22 \\
\hline Content weight, g & $229^{\mathrm{ab}}$ & $231^{\mathrm{ab}}$ & $242^{\mathrm{ab}}$ & $276^{\mathrm{a}}$ & $223^{\mathrm{ab}}$ & $194^{\mathrm{b}}$ & 10.71 \\
\hline$\%$ of SW & $9.27^{\mathrm{ab}}$ & $9.49^{\mathrm{ab}}$ & $9.90 \mathrm{ab}$ & $11.20^{\mathrm{a}}$ & $9.16^{\mathrm{ab}}$ & $7.94^{\mathrm{b}}$ & 0.41 \\
\hline
\end{tabular}

External offal's: included (Head, fur, legs and ears).

$a$, and $b$ : Means in the same row having different superscripts differ significantly $(P<0.5)$. 
Table 11. Economical evaluation of the experimental groups

\begin{tabular}{|c|c|c|c|c|c|c|}
\hline \multirow{4}{*}{ Item } & \multicolumn{6}{|c|}{ Experimental diets } \\
\hline & \multirow{2}{*}{\multicolumn{3}{|c|}{$\begin{array}{l}100 \% \\
\text { Energy requirements }\end{array}$}} & \multirow{2}{*}{\multicolumn{3}{|c|}{$\begin{array}{l}90 \% \\
\text { Energy requirements }\end{array}$}} \\
\hline & & & & & & \\
\hline & $\mathrm{G}_{1}$ & $\mathrm{G}_{2}$ & $\mathrm{G}_{3}$ & $\mathrm{G}_{4}$ & $\mathrm{G}_{5}$ & $\mathrm{G}_{6}$ \\
\hline Marketing weight, $\mathrm{Kg}$ & 2.396 & 2.424 & 2.427 & 2.411 & 2.440 & 2.449 \\
\hline Feed consumed / rabbit, kg & 6.373 & 6.367 & 6.373 & 6.938 & 6.334 & 6.345 \\
\hline Costing of one $\mathrm{kg}$ feed, $(\mathrm{LE})^{1}$ & 2.197 & 2.252 & 2.298 & 2.045 & 2.100 & 2.126 \\
\hline Total feed cost, (LE) & 14.00 & 14.34 & 14.65 & 14.19 & 13.30 & 13.49 \\
\hline Management/ Rabbit, (LE) $)^{2}$ & 4 & 4 & 4 & 4 & 4 & 4 \\
\hline Total cost, $(\mathrm{LE})^{3}$ & 30.00 & 30.34 & 30.65 & 30.19 & 29.30 & 29.49 \\
\hline Total revenue, $(\mathrm{LE})^{4}$ & 47.92 & 48.48 & 48.54 & 48.22 & 48.80 & 48.98 \\
\hline Net revenue & 17.92 & 18.14 & 17.89 & 18.03 & 19.50 & 19.49 \\
\hline Economical efficiency ${ }^{5}$ & 0.5973 & 0.5979 & 0.5837 & 0.5972 & 0.6655 & 0.6609 \\
\hline Relative economic efficiency ${ }^{6}$ & 100 & 100.1 & 97.7 & 99.98 & 111.4 & 110.6 \\
\hline Feed cost / kg LBW (LE) ${ }^{7}$ & 5.84 & 5.92 & 6.04 & 5.89 & 5.45 & 5.51 \\
\hline
\end{tabular}

${ }^{1}$ Based on prices of year 2010.

${ }^{2}$ Include medication, vaccines, sanitation and workers.

${ }^{3}$ include the feed cost of experimental rabbit which was LE 12/ rabbit + management.

${ }^{4}$ Body weight $x$ price of one $\mathrm{kg}$ at selling which was LE 20.

${ }^{5}$ net revenue per unit of total cost.

${ }^{6}$ Assuming that the relative economic efficiency of control diet equal 100.

${ }^{7}$ Feed cost $/ \mathrm{kg} L B W=$ feed intake * price of $\mathrm{kg} /$ Live weight. 